\title{
REFORMING PENSION INSURANCE IN THE PEOPLE'S REPUBLIC OF CHINA
}

Keyong Dong and Donghyun Park

NO. 19

December 2019

\section{ADB EAST ASIA WORKING PAPER SERIES}


ADB East Asia Working Paper Series

\section{Reforming Pension Insurance in the People's Republic of China}

Keyong Dong and Donghyun Park

No. 19 | December 2019
Keyong Dong, PhD, is a professor of School of Public Administration and Policy at Renmin University of China.

Donghyun Park is a principal economist, Macroeconomics Research Division (ERMR), Economic Research and Regional Cooperation Department (ERCD), Asian

Development Bank. 
(C) 2019 Asian Development Bank

6 ADB Avenue, Mandaluyong City, 1550 Metro Manila, Philippines

Tel +632 8632 4444; Fax +63286362444

www.adb.org

Some rights reserved. Published in 2019.

Printed in the Philippines

Publication Stock No. WPS190589-2

DOI: http://dx.doi.org/10.22617/WPS190589-2

The views expressed in this publication are those of the authors and do not necessarily reflect the views and policies of the Asian Development Bank (ADB) or its Board of Governors or the governments they represent.

ADB does not guarantee the accuracy of the data included in this publication and accepts no responsibility for any consequence of their use. The mention of specific companies or products of manufacturers does not imply that they are endorsed or recommended by ADB in preference to others of a similar nature that are not mentioned.

By making any designation of or reference to a particular territory or geographic area, or by using the term "country" in this document, $A D B$ does not intend to make any judgments as to the legal or other status of any territory or area.

This work is available under the Creative Commons Attribution 3.0 IGO license (CC BY 3.0 IGO)

https://creativecommons.org/licenses/by/3.0/igo/. By using the content of this publication, you agree to be bound by the terms of this license. For attribution, translations, adaptations, and permissions, please read the provisions and terms of use at https://www.adb.org/terms-use\#openaccess.

This CC license does not apply to non-ADB copyright materials in this publication. If the material is attributed to another source, please contact the copyright owner or publisher of that source for permission to reproduce it. $A D B$ cannot be held liable for any claims that arise as a result of your use of the material.

Please contact pubsmarketing@adb.org if you have questions or comments with respect to content, or if you wish to obtain copyright permission for your intended use that does not fall within these terms, or for permission to use the ADB logo.

Corrigenda to ADB publications may be found at http://www.adb.org/publications/corrigenda.

Notes:

In this publication, "CNY" refers to yuan as the currency unit used in the People's Republic of China.

ADB recognizes "China” as the People's Republic of China.

The ADB East Asia Working Paper Series is a forum for stimulating discussion and eliciting feedback on ongoing and recently completed research and policy studies undertaken by the East Asia Department of the Asian Development Bank (ADB) staff, consultants, or resource persons. The series deals with key economic and development problems, as well as conceptual, analytical, or methodological issues relating to project/program economic analysis, and statistical data and measurement. The series aims to enhance the knowledge on Asia's development and policy challenges; strengthen analytical rigor and quality of ADB's country partnership strategies, and its subregional and country operations; and improve the quality and availability of statistical data and development indicators for monitoring development effectiveness.

The ADB East Asia Working Paper Series is a quick-disseminating, informal publication whose titles could subsequently be revised for publication as articles in professional journals or chapters in books. The series is maintained by the East Asia Department.

This paper was prepared as a background study for the preparation of the High-Level Round Table Discussion on the People's Republic of China's transition to high-quality development, coordinated by the Asian Development Bank. 


\section{CONTENTS}

TABLE AND FIGURES

iv

ABSTRACT

ABBREVIATIONS vi

$\begin{array}{ll}\text { I. INTRODUCTION } & 1\end{array}$

II. CURRENT STATE OF PENSION INSURANCE 1

A. Basic Pension Insurance Participation 1

B. Income and Expenditure of Basic Pension Insurance Funds 1

C. Benefit Levels 3

III. PENSION POLICY DEVELOPMENTS DURING THE 13TH FIVE-YEAR PLAN 3

A. Unified Pension Systems for Public and Private Sector Employees 3

B. Unified Basic Pension Systems for Urban and Rural Residents 4

C. Lower Contribution Rates in Enterprise Employee Basic Pensions 4

D. Piloting Tax-Deferred Personal Commercial Pension Insurance 5

IV. CHALLENGES FACING THE PENSION INSURANCE SYSTEM 5

A. Nationwide Pooling Not Yet Achieved for Urban Employee Pensions 5

B. High Contribution Rate $\quad 5$

C. Retirement Age Too Low and Widespread Early Retirement 6

D. Excessively Generous Pension Conditions 6

E. Insufficient Investment in Basic Pension Insurance Balances 6

F. Inadequate Transfer of State Capital to Social Security Funds 7

G. Pensions Lack Benefit Adjustments and a Contribution Incentive Mechanism 7

H. Little Growth in the Enterprise Annuity System 7

I. Long-Term Pension System Sustainability Concerns 8

V. REFORM FOCUS OF PENSION INSURANCE 10

A. Accelerate Pooling of Urban Employees' Basic Pensions 10

B. Consolidate Contribution Base and Cut Contribution Rate 10

C. Start Delayed Retirement Program 10

D. Improve the Capital Transfer System 10

E. Set Up Mechanisms for Adjusting Contributions and Benefits

F. Lower the Threshold for Establishing Enterprise Annuities 11

G. Accelerate the Setting Up of Personal Pensions 11

$\begin{array}{ll}\text { VI. CONCLUSIONS } & 12\end{array}$

$\begin{array}{lr}\text { REFERENCES } & 13\end{array}$ 


\section{TABLE AND FIGURES}

\section{TABLE}

1 Income, Expenditure, and Financial Subsidies of Basic Pension Insurance Funds, 2002-2017

\section{FIGURES}

1 Basic Pension Insurance Participation, 2010-2017 2

2 Income and Expenditure of the Basic Pension Insurance Funds, 2010-2017 2

3 Basic Pension Levels of Urban Enterprise Retirees, 2011-2016 3

4 Composition of the Basic Pension Insurance System 4

5 Enterprise Annuity Indicators, 2007-2017 8 


\begin{abstract}
Rapid population aging is drastically changing the demographic landscape in the People's Republic of China (PRC), making affordable, adequate, and sustainable old-age income support a top strategic challenge. The cornerstone of old-age economic security is a robust pension insurance system. This paper reviews the progress made in strengthening the system during the 13th Five-Year Plan period, and identifies the challenges and priorities for pension reform. Although great progress in pension system integration has been made during the plan period, pension reform remains a work in progress. If a big effort is made on pension reform, the chances are very good that the PRC can build a national pension insurance system that provides its large and growing elderly population with economic security. This will be vital for the country's aim to become a "moderately prosperous and socially harmonious society."
\end{abstract}

Keywords: pension reform, population aging, inclusive growth, People's Republic of China 


\section{ABBREVIATIONS}

PRC People's Republic of China

EET exemption, exemption, taxation

TEE taxation, exemption, exemption 


\section{INTRODUCTION}

Rapid population aging in the People's Republic of China (PRC) is stoking concerns that the country will grow old before it becomes rich (Lee, Mason, and Park 2012). This massive demographic change presents two strategic challenges. First, the PRC must find ways to sustain economic growth in the face of less favorable demographics. A demographic dividend associated with a young population of many workers is giving way to a demographic tax associated with an older population with many dependents. Second, the PRC must deliver affordable, adequate, and sustainable old-age income support for its large and growing elderly population (Park and Estrada 2011; Park 2009). Given the speed and scale of the aging of PRC's population, failing to do this will impoverish and marginalize a large segment of the people. Providing economic security for the elderly will therefore need to be an integral part of the PRC's quest to become a moderately prosperous and socially harmonious society.

A sound national pension insurance system is needed to provide this economic security (Chen, Eggleston, and Li 2012). Income support for the elderly comes in many forms, including family transfers, working into old age, and personal savings. But pensions must be at the front and center of any viable old-age economic security system. A well-designed pension insurance system should be robust enough to provide a safety net for the elderly poor (Park and Estrada 2012; 2014). The PRC has made great progress in building a national pension insurance system since the 1990s, but this remains a work in progress. This paper reviews the current state of pension insurance and the progress made under the 13th Five-Year Plan using the main indicators of pension development. It then examines the challenges and priorities for pension reform.

\section{CURRENT STATE OF PENSION INSURANCE}

\section{A. Basic Pension Insurance Participation}

Figure 1 shows a sharp rise in the number of people in rural and urban areas with basic insurance since 2010. As of 2010, there were only 360 million participants. By the end of 2017 , this totaled 915 million, up from 888 million at the end of 2016. The participation in pension insurance of urban workers, and urban and rural residents, increased significantly during this period.

\section{B. Income and Expenditure of Basic Pension Insurance Funds}

The income and expenditure of basic pension funds in the PRC are on the rise in a trend that is in line with the increase in the number of participants (Figure 2). Income increased from CNY3.8 trillion in 2016 to CNY4.7 trillion in 2017, an increase of $22.7 \%$. In 2017, contributions by basic insurance participants accounted for CNY3.4 trillion of that year's income, up 24.4\% from 2016. The annual expenditure of basic pension insurance funds totaled CNY4.0 trillion in 2017, up 18.9\% from 2016. At the end of 2017, as a result of surpluses in recent years, the funds had a cumulative balance of CNY5.0 trillion. 


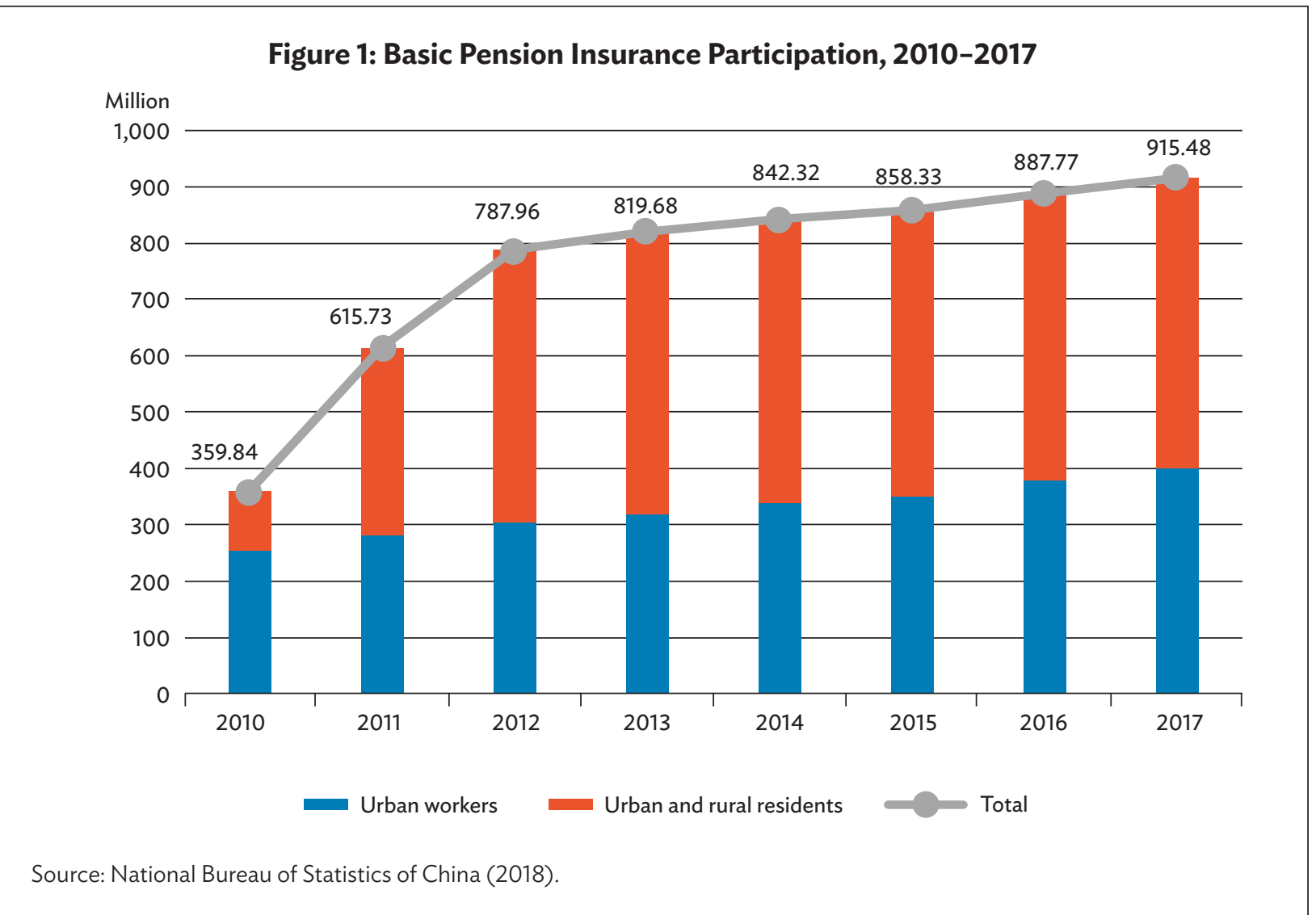

Figure 2: Income and Expenditure of the Basic Pension Insurance Funds, 2010-2017 Billion 6,000

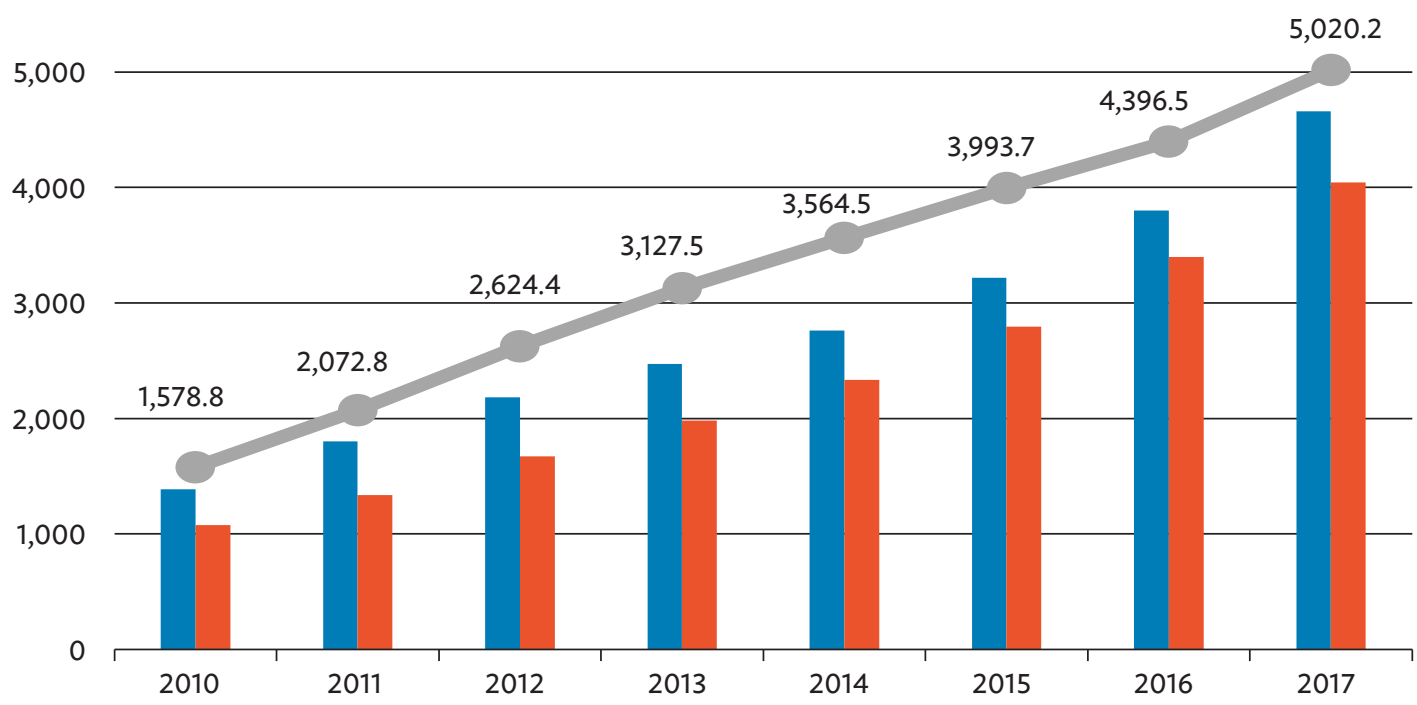

Fund income 


\section{Benefit Levels}

Only adequate pension benefits can provide economic security for the elderly. Basic pension insurance benefits have been steadily rising in the PRC, with the average monthly pension insurance for urban employees at CNY2,362 in 2016 (Figure 3).

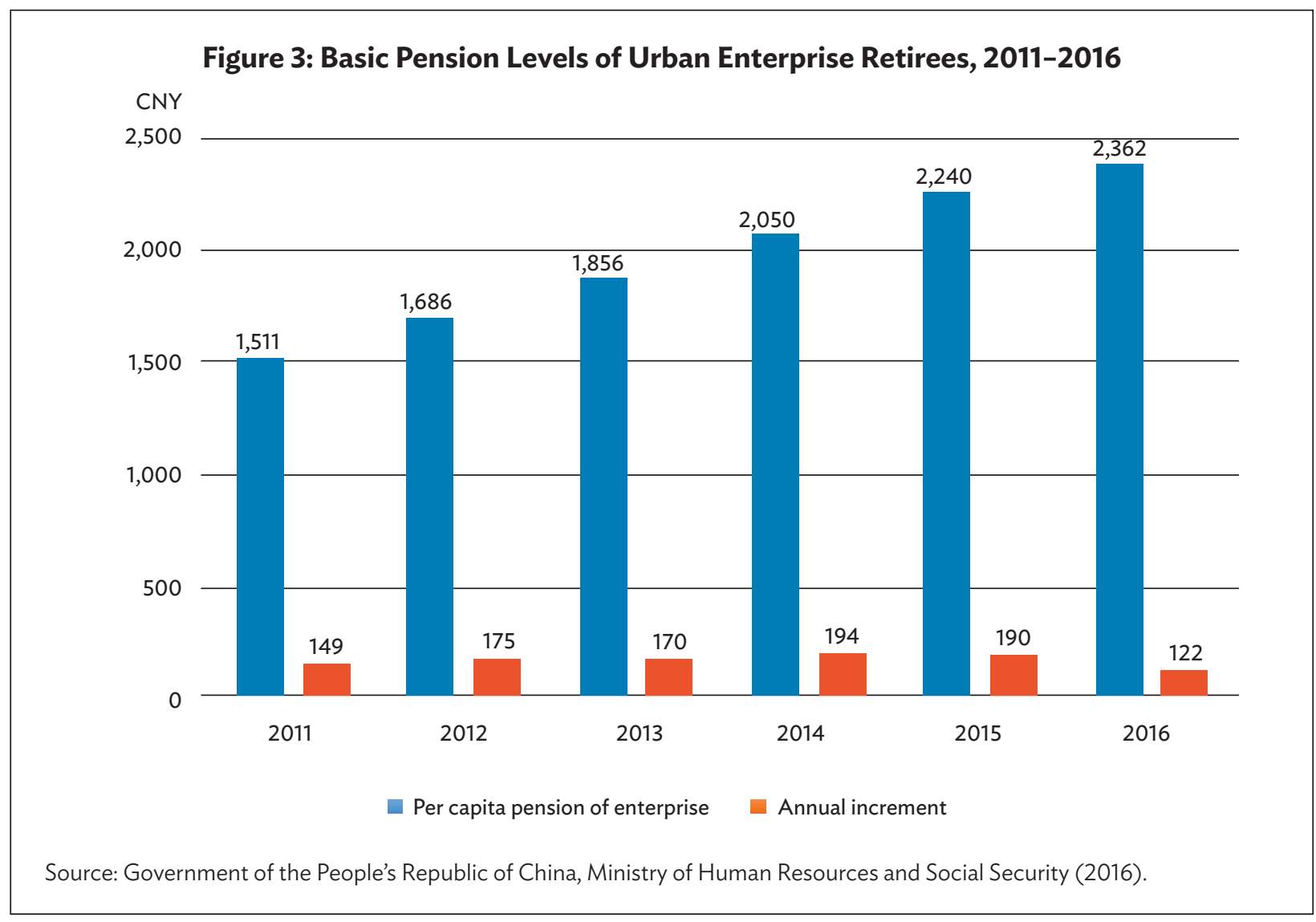

\section{PENSION POLICY DEVELOPMENTS DURING THE 13TH FIVE-YEAR PLAN}

The 13th Five-Year Plan (2016-2020) has been characterized by steady progress in building up a sound and efficient pension insurance system, and significant policy developments that can promote further progress. This section looks at the major policy developments over the plan period.

\section{A. Unified Pension Systems for Public and Private Sector Employees}

In 2015, the State Council required government bodies and institutions to implement a basic pension insurance system that combines social pooling and individual accounts. ${ }^{1}$ The decision also established 
an occupational annuity system. In 2016, 2017, and 2018, the Ministry of Human Resources and Social Security and the Ministry of Finance jointly improved the basic pension levels of retirees from the private sector, government bodies, and public institutions. ${ }^{2}$ In year-on-year increases, these rose from $5.5 \%$ in 2016 , to $5.5 \%$ in 2017 , and $5.0 \%$ in 2018.

\section{B. Unified Basic Pension Systems for Urban and Rural Residents}

In 2015, the unified basic pension insurance system for urban and rural residents was implemented nationwide, covering 505 million people in 2016 and 513 million in 2017. Figure 4 shows the system's structure. Income totaled CNY330 billion in 2017, an increase of $12.6 \%$ over 2016. Individual contributions accounted for CNY81 billion in 2017; expenditure totaled CNY237 billion, up 10.3\% from 2016. The accumulated balance of the funds was CNY632 billion (Ministry of Human Resources and Social Security 2017).

\section{Figure 4: Composition of the Basic Pension Insurance System}

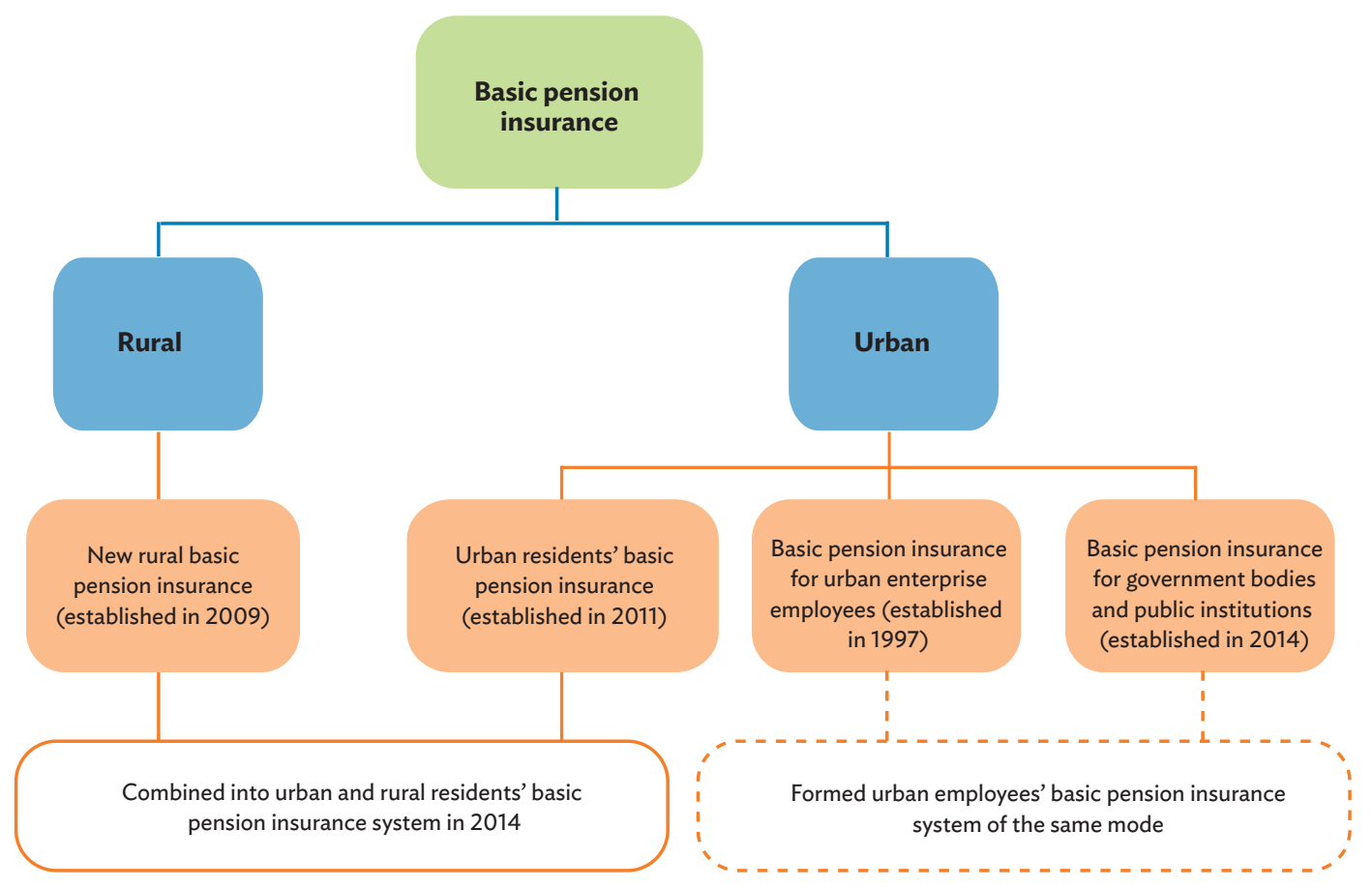

Source: Asian Development Bank.

\section{Lower Contribution Rates in Enterprise Employee Basic Pensions}

The Ministry of Human Resources and Social Security and the Ministry of Finance jointly lowered employee contribution rates from May 2018 to 19\%. ${ }^{3}$ This applies to provinces, autonomous regions,

2 Government of the People's Republic of China, Ministry of Human Resources and Social Security. Notice of the Ministry of Human Resources and Social Security on Adjusting the Basic Pensions for Retired Persons, 2016, No. 37; 2017, No. 30; 2018, No.18.

3 Government of the People's Republic of China, Ministry of Human Resources and Social Security. 2018. Notice of the Ministry of Human Resources and Social Security on Continuing the Phased Reduction of Social Insurance Rates. No. 25. 
and municipalities where employers contribute more than $19 \%$ to the basic pension insurance of urban employees. In April 2019, the State Council wanted to further reduce the proportion that employers are required to pay for the basic pension insurance of urban employees. ${ }^{4}$ Under the notice, the proportion paid in any provinces can be reduced to 16\% if it is higher than that as of May 2019.

\section{Piloting Tax-Deferred Personal Commercial Pension Insurance}

The Ministry of Finance piloted tax-deferred commercial pension insurance in May 2018 in Shanghai Municipality, Fujian Province (including Xiamen), and Suzhou Industrial Park. The pilot period was tentatively set for 1 year. Under the terms, individuals can take out CNY1,000 a month from their salary to buy insurance products. There are no circumstances in which contributions paid in the scheme could be taken out before retirement. The tax-exemption mode is the so-called EET tax treatment-exemption, exemption, taxation. A $25 \%$ reduction in taxable benefits was granted; the tax rate is $10 \%$.

\section{CHALLENGES FACING THE PENSION INSURANCE SYSTEM}

Despite the progress being made in building a stronger and more efficient pension insurance system, and the reforms made during the 13th Five-Year Plan period, pension insurance reform in the PRC is still a work in progress in which major obstacles need to be removed before the PRC's pension insurance system can be considered world class. This section examines these obstacles.

\section{A. Nationwide Pooling Not Yet Achieved for Urban Employee Pensions}

Basic pension insurance in the PRC still uses a regional rather than a national pooling scheme that unites all provinces and cities into a single national system. Regional pooling is inherently less efficient than national pooling, which can achieve substantial economies of scale. National pooling in turn can lead to lower costs, which benefit participants. It can also contribute to the enhanced portability of pension benefits, which would contribute to the greater mobility of workers (Zheng 2015). The regional pooling of basic pensions gives rise to many complications, including inconsistent policy standards and inefficient pension investments.

\section{B. High Contribution Rate}

A high contribution rate can discourage participation in and compliance with a pension insurance system. The contribution rate must also not be too low either, because this could jeopardize the system's financial sustainability. Setting an optimal contribution rate is a delicate balancing act. Before 2019, the nominal contribution rate of basic pension insurance was $28 \%$ - with the employer contributing $20 \%$ and the employee $8 \%$. This was significantly higher than the average of $20 \%$ for public pension contributions in Organisation for Economic Co-operation and Development (OECD) countries.

A high contribution rate is a disincentive for employers to comply with pension insurance regulations because it means higher labor costs. Consequently, enterprises have reduced their labor income base, which is the basis for contributions (Chen 2017). Under current pension policies, the contribution rate

4 Government of the People's Republic of China, State Council. 2019. Notice of the General Office of the State Council on Printing and Distributing the Comprehensive Plan for Reducing the Social Insurance Rate. No. 13. 
can be between $60 \%$ and $300 \%$ of the average wage of the local economy. Many companies set their contribution rate at the lowest level.

\section{Retirement Age Too Low and Widespread Early Retirement}

The statutory retirement age is 60 years for men, 55 years for women cadres, and 50 years for women workers. The retirement age is rooted in the socioeconomic conditions and life expectancy of the 1950s, when the PRC was a much poorer country. Since the market reforms of the late 1970s, sustained economic growth has drastically improved living standards and people now enjoy incomparably better nutrition, health care, and overall living conditions. By 2015, the average life expectancy was 76.3 years -73.6 years for men and 79.4 years for women. ${ }^{5}$ Not only is life expectancy much longer, but healthy life expectancy-the age until individuals remain relatively healthy-has increased. Taking all these factors into account, the current statutory retirement age is too low, especially for women (Leckie 2012).

Widespread early retirement is adding to the problem of a retirement age that does not reflect current demographic realities. According to the Ministry of Human Resources and Social Security, many workers retire before reaching a statutory retirement age that is already too low. In some parts of the country, early retirees account for about 30\% of all retirees, and the average actual retirement age is only 54 years (Beijing News 2017). Early retirement is a serious risk for the financial sustainability of the pension insurance system, because it increases the number of effective retirees relative to the number of effective workers.

\section{Excessively Generous Pension Conditions}

Excessively generous pension conditions are causing the widespread termination of contributions. Under the Social Security Law of 2010, those who participate in basic pension insurance receive a basic pension once they reach the statutory retirement age and have paid pension contributions for 15 years (Yang and He 2016). In other words, workers can simply pay in the 15 years and make no more contributions until their statutory retirement ages even though they are continuing to work. It is estimated that 20 million workers have done this in 2017. ${ }^{6}$ This is affecting the financial sustainability of the pension insurance system.

\section{E. Insufficient Investment in Basic Pension Insurance Balances}

The scale and proportion of basic pension insurance funds investment is far too small. Basic pension insurance in the PRC is still provincial-level pooling. In some areas, there are funds balances. The central government hopes to pool the balances from various provinces to improve investment efficiency. As of 2018, the accumulated balance of urban employees' basic pension insurance totaled CNY5.1 trillion. However, the accumulated basic pension funds of 17 provinces, autonomous regions, and municipalities totaled only CNY858 billion. Furthermore, the actual amount of balances transferred to the funds was smaller still, at CNY605 billion. Therefore, only $12 \%$ of the accumulated balances of individuals are invested in pension funds.

Data from the National Bureau of Statistics of China.

6 Calculated based on data from the National Bureau of Statistics of China and the Human Resources and Social Security Bureau. 


\section{F. Inadequate Transfer of State Capital to Social Security Funds}

Because social security funds (especially pensions) need to be financially sustainable in the long term, in 2001, the central government began to replenish these funds by transferring some state-owned shares to them. But this has only had a very limited effect on improving their financial sustainability (Sun 2019).

At the end of 2017, state-owned shares and funds reduced or transferred to replenish social security funds totaled CNY283 trillion. In that year, the total assets of state-owned enterprises were CNY152 trillion, accounting for less than $0.2 \%$ of the former. In 2017, the total profits of state-owned enterprises was CNY2.9 billion, but the funds and shares of state-owned shares reduced or transferred to social security funds was only CNY8 billion. ${ }^{7}$ The anemic strength and speed of the transfers are compromising the objective of strengthening social security funds through more fund injections.

A 2017 State Council decision selected some central enterprises and provinces for a pilot program to uniformly transfer $10 \%$ of state-owned shares of enterprises to replenish social security funds. ${ }^{8}$ The implementation of this has also been low, and many obstacles remain for implementing the State Council's decision.

\section{G. Pensions Lack Benefit Adjustments and a Contribution Incentive Mechanism}

Setting up a benefit adjustment mechanism to rationalize the level of benefits, and a contribution incentive mechanism to motivate individual contributions will be vital for improving the pension system's sustainability. ${ }^{9}$ There is currently only a broad conceptual assessment of the wide range of factors, the mechanism itself has not yet been put in place. There are no specific directions on how the basic pension of rural and urban residents is linked to their income, or specific guidance on how the basic pension is linked to price levels.

The incentives for individuals to contribute to the basic pension scheme are insufficient. The contribution amounts have 12 grades, ranging from CNY100 to CNY2,000 a year. These grades are neither strongly correlated to government subsidies nor to the final amount of pension benefits, and there is no mechanism to incentivize participants to choose higher grades. This means that most choose the lowest level of contributions. The principle of more returns on higher contributions remains a distant goal in the PRC.

\section{H. Little Growth in the Enterprise Annuity System}

By the end of 2017, some 80,000 companies had set up enterprise annuity programs, 23 million employees had enrolled in them, and their accumulated funds totaled CNY1.3 billion (Figure 5).

Data from State-Owned Assets Supervision and Administration Commission of the State Council website. http://en.sasac. gov.cn/

8 Government of the People's Republic of China, State Council. 2017. The Decision of the State Council on Implementation Plan for Transferring Some State Owned Capitals to replenish Social Security Funds. No. 49.

9 This opinion is mentioned in the Decision of State Council on Establishing a Unified Basic Pension Insurance System for Urban and Rural Residents, 2014, No. 8. 
Figure 5: Enterprise Annuity Indicators, 2007-2017

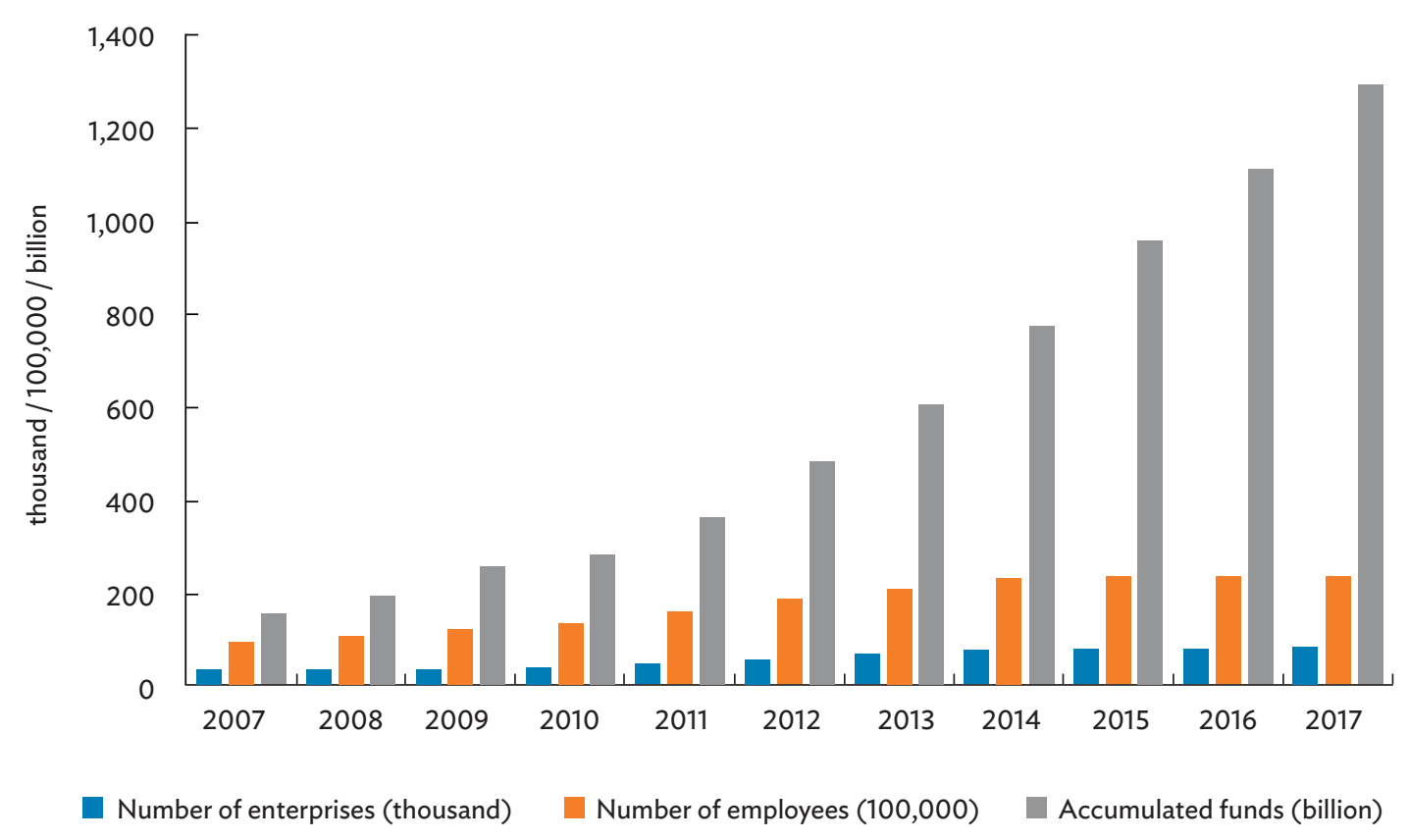

Source: Government of the People's Republic of China, Ministry of Human Resources and Social Security (2017).

Although the coverage rate of enterprise annuities is expanding, it still is far too low compared with basic pension insurance (Leckie 2011). At the end of 2017, less than 10\% of companies nationwide had enterprise annuities, and the number of employees participating in them was only $5.5 \%$ of the urban employee population. These very low participation rates suggest there is a long way to go before the enterprise annuity system become integral to the PRC's pension insurance system (Zheng 2017).

\section{Long-Term Pension System Sustainability Concerns}

One of the biggest structural problems facing the PRC's pension insurance system is that it is not financially sustainable (Zhao and Mi 2019). Rapid population aging suggests this problem will likely worsen in the absence of major reforms to improve sustainability (Leckie 2012).

Worryingly, the gap between the size of government spending on the pension insurance system and the system's income continues to widen. During 2011-2017, the average annual growth rate of the total income of basic pension insurance funds for urban employees was $18.3 \%$; the average annual growth rate of spending was $20.1 \%$. Table 1 shows the state's financial subsidies for basic pension insurance for urban employees increased every year from 2002 to 2017, reaching CNY800 billion by 2017. In that year, the balance of these funds was CNY4.4 trillion, but all of that came from financial subsidies provided by the state over the years. Pension insurance for urban and rural residents also relies on financial subsidies; these increased from CNY21.7 billion in 2010 to CNY249.4 billion in 2017, and have long accounted for more than $70 \%$ of the funds' income. 
There is a danger that rising subsidies could cause the government's long-term fiscal stability to deteriorate. The structure of the population matters for public finances for the simple reason that the government tends to spend more on the young (on education, for example) and the elderly (on pensions and health care, for example). Population aging means that fiscal spending on the elderly may grow rapidly and pose a serious risk to long-term fiscal sustainability. Given these risks, the government should analyze the fiscal implications of rapid population aging. Reforms to the pension insurance system that improve its financial health can contribute not only to improving its financial sustainability but also its long-term fiscal health.

Table: Income, Expenditure, and Financial Subsidies of Basic Pension Insurance Funds, 2002-2017

\begin{tabular}{|c|c|c|c|c|c|c|c|c|}
\hline \multirow[b]{2}{*}{ Year } & \multicolumn{4}{|c|}{$\begin{array}{c}\text { Urban Employees' Basic Pension Insurance } \\
\text { (yuan billion) }\end{array}$} & \multicolumn{4}{|c|}{$\begin{array}{l}\text { Urban and Rural Residents' Basic Pension Insurance } \\
\text { (yuan billion) }\end{array}$} \\
\hline & Revenue & Expenditure & Balance & Subsidies & Revenue & Expenditure & Balance & Subsidies \\
\hline 2002 & 317 & 284 & 161 & 41 & & & & \\
\hline 2003 & 368 & 312 & 221 & 53 & & & & \\
\hline 2004 & 426 & 350 & 298 & 61 & & & & \\
\hline 2005 & 509 & 404 & 404 & 65 & & & & \\
\hline 2006 & 631 & 490 & 549 & 97 & & & & \\
\hline 2007 & 783 & 596 & 739 & 116 & & & & \\
\hline 2008 & 974 & 739 & 993 & 144 & & & & \\
\hline 2009 & 1,149 & 889 & 1,253 & 165 & & & & \\
\hline 2010 & 1,342 & 1,055 & 1,537 & 195 & 45 & 20 & 42 & 22 \\
\hline 2011 & 1,689 & 1,276 & 1,950 & 227 & 111 & 60 & 123 & 69 \\
\hline 2012 & 2,000 & 1,556 & 2,394 & 265 & 183 & 115 & 230 & 124 \\
\hline 2013 & 2,268 & 1,847 & 2,827 & 302 & 205 & 135 & 301 & 142 \\
\hline 2014 & 2,531 & 2,175 & 3,180 & 355 & 231 & 157 & 384 & 164 \\
\hline 2015 & 2,934 & 2,581 & 3,534 & 472 & 285 & 212 & 459 & 216 \\
\hline 2016 & 3,506 & 3,185 & ,3858 & 651 & 293 & 215 & 539 & 220 \\
\hline 2017 & 4,331 & 3,805 & 4,389 & 800 & 330 & 237 & 632 & 249 \\
\hline
\end{tabular}

Source: Statistical bulletins from the Ministry of Human Resources and Social Security of the People's Republic of China from various years on the development of human resources and social security.

The regional financial sustainability trends of the PRC's basic pension insurance system are not encouraging. The number of regions where government spending on the system exceeds income is rising. Furthermore, the number of provinces where this is the case for the basic pension insurance funds of urban employees has gone from three (Hebei, Heilongjiang, and Ningxia) in 2014 to seven in 2016 (Hebei, Heilongjiang, Hubei, Inner Mongolia, Jilin, Liaoning, Inner Mongolia, and Qinghai). If financial subsidies are not taken into account, there would be a funding gap for pensions in more than 20 provinces, autonomous regions, and special municipalities in 2017. 


\section{REFORM FOCUS OF PENSION INSURANCE}

While there is plenty of scope for reforming the PRC's pension insurance system, a great deal of progress has been made - and is being made under the 13th Five-Year Plan - to build a system that can deliver affordable, adequate, and sustainable old-age income support for the country's growing elderly population. This section offers recommendations on the substantial reforms that still need to be made to the system and the priority areas.

\section{A. Accelerate the Pooling of Urban Employees' Basic Pensions}

The PRC still lacks a nationally unified basic pension insurance for urban employees, and the current system remains fragmented along regional lines. Moving from regional to national pooling will require two interrelated reforms - the method for calculating the contribution base needs be unified across regions, and contribution rates into the basic pension insurance system need to be unified nationwide. A first step has been taken to unify contribution rates. This is being carried out in conjunction with the launch of national tax collection, reforms to the pension management system, and a comprehensive plan to reduce the social security rate. These reforms need to be completed as soon as possible.

\section{B. Consolidate Contribution Base and Cut Contribution Rate}

The current contribution base of the basic pension insurance system is putting an uneven tax burden on industries and regions (Leckie 2012). This compromises the principle of equity, reduces confidence in the basic pension insurance system, and acts as a disincentive to compliance and participation. The lack of a realistic and clear contribution base plays a major role in widening the basic pension income gap and will aggravate the coming sustainability concern. The contribution amount is jointly determined by the contribution base and rate. There are two parts to the contribution base: the individual contribution base, and the unit contribution base. When the contribution base is clear, the high contribution rate will decrease (Dong and Shi 2019).

\section{Start Delayed Retirement Program}

A major needed reform is the launch of the delayed retirement program, as life expectancy is increasing and the elderly population expanding. To enhance the attractiveness of delayed retirement, it will be necessary to link the retirement age to the pension entitlement ratio. The thrust of this reform should be to reinforce the incentive mechanism for individuals to work longer and retire later, so that the length of the working life and retirement age are more in line with the PRC's demographic realities. A key component of this reform should be to strengthen the proportion of individual contributions in the formula for calculating benefits, thereby encouraging participants to extend the period during which they make contributions into the retirement insurance funds.

\section{Improve the Capital Transfer System}

A clear strategy is needed for planning the transfers of state-owned capital from central and local governments to social security funds, including their schedule and transfer amounts. Many other issues related to the capital transfer system still need to be clarified, including how the National Social Security Fund Council will deal with the state-owned capital - that is, whether to hold or sell. Another issue is the collaborative management of central and regional state-owned capital. 
Four recommendations are offered for improving the capital transfer system. First, reducing the pension gap should be the goal of this strategy. Second, the method for the collaborative management of state-owned capital transferred by the central and regional governments should be systematically designed. Third, the transfer amounts should be more flexible and dynamically adjusted as needed. Finally, the National Social Security Fund Council needs to carefully consider the management mode for state-owned capital.

\section{E. Set Up Mechanisms for Adjusting Contributions and Benefits}

It is essential to have mechanisms for adjusting benefits and incentivizing individual contributions and to accelerate the identification of specific adjustments and decision-making mechanisms. Policy directions in particular are needed to specify how the basic pension benefits of urban and rural residents are to be linked to their income, prices, and the basic pension insurance of employees. The government should improve the incentive effect of financial subsidies on contributions, strengthen the incentive mechanism for making insurance contributions, and induce participants to choose higher levels of contributions. All these measures are needed to advance a more sustainable and dynamic development of the basic pension insurance system for urban and rural residents.

\section{F. Lower the Threshold for Establishing Enterprise Annuities}

The strategic priority of pension reform should be to strengthen the system's first pillar through the suggested reforms just outlined..$^{10}$ At the same time, as an integral part of the process of developing a robust multi-pillar pension insurance system, the authorities should reform the second pillar (Leckie 2011). Here, the core issue that needs to be resolved is the need to expand the coverage of the enterprise annuity system. The system, as noted earlier, is underdeveloped and shows little signs of growth. To rectify this, the government should explore the possibility of reducing or even eliminating the threshold for setting up an enterprise annuity and introduce an automatic mechanism for joining. The government should consider liberalizing and expanding the range of options for employees to participate. It could also improve the EET-type tax incentive policy by setting the tax threshold for enterprise annuities after retirement, among others. Collectively, these reforms could inject much-needed vitality into the stagnant enterprise annuity system (Zheng 2017).

\section{G. Accelerate the Setting Up of Personal Pensions}

Although the immediate priority for constructing a multi-pillar pension insurance system is to build a strong second pillar, the government should start planning the third pillar of personal pensions (Holzmann and Hinz 2005; World Bank 1994). The third pillar is an integral and indispensable component of a wellfunctioning and sustainable multi-pillar pension insurance system. To do this, three recommendations are offered: First, the government should explore the possibility of building an institutional model centered on individual accounts (personal pensions are based on individual accounts that keep track of an individual's contributions and future benefits). Second, the government should design and implement an effective tax incentive model, including the appropriate use of EET or so-called TEE (taxation, exemption, exemption) to promote greater participation. Third, the government should expand and diversify investment channels and products. In the absence of attractive investment opportunities, the third pillar will fail to attract participants - and without strong participation, it will not take off (Dong and Wang 2016; Dong 2019).

10 In 1994, the World Bank proposed a three-pillar model of pension system. They are a safety net for adequacy (1st pillar), mandatory income replacement (2nd pillar), and voluntary saving (3rd pillar). In 2005, the World Bank further proposed a five-pillar model. The first pillar is noncontributory and public; the second pillar is contributory, mandated, and public; the third pillar is contributory, mandated, and private; the four pillar is contributory, voluntary, and private; and the fifth pillar is other kind of support. 


\section{CONCLUSIONS}

The PRC is following in the demographic footsteps of Japan and Republic of Korea. But the country's large population, coupled with the unparalleled speed and scale of its population aging, is characterized by two additional features not common to the other countries-a rapid increase in the old-age dependency ratio (the ratio of retirees to younger workers) and population aging at a relatively lowincome level. This poses two strategic challenges: the PRC must sustain rapid economic growth in the face of less favorable demographic conditions, and it must deliver affordable, adequate, and sustainable old-age economic security for its large and rapidly growing elderly population. At the same time, the pattern of that economic growth must be inclusive, because growth that is still grounded on quantity will merely leave behind an important segment of the population.

That an integral part of any country's old-age income support system is its pension insurance is especially true in Asian countries, which are undergoing extensive economic, social, and cultural changes that are weakening family support (Park and Estrada 2011). The underdeveloped financial markets of many countries in the region have meant that support from the grown-up children of elderly parents traditionally played a key role in the region's income support for the elderly. The lack of a robust and sustainable pension insurance system could create a dangerous vacuum for the economic security of the elderly. In the Republic of Korea, the mix of rapid population aging and the late establishment of a national pension insurance system turned widespread poverty among the elderly into a large economic and social risk. In the PRC, where there are growing concerns that the country may grow old before it becomes rich, the lack of an efficient pension insurance system could endanger the objective of a moderately prosperous and socially harmonious society (Dorfman et al. 2013).

Despite the PRC's rapid population aging and its underdeveloped pension insurance system, the outlook for achieving economic security for the elderly is far from gloomy. Encouragingly, all major development indicators of the PRC's pension insurance system are showing substantial improvement. Furthermore, the government is making a substantial effort to strengthen and enhance policies relevant to the system. Indeed, the 13th Five-Year Plan period has seen tangible improvements in pension policies.

Even so, the PRC's pension insurance system is a work in progress that still faces structural challenges. To rise to these challenges, the government must reinforce and accelerate pension reform by shifting from regional to national pooling, raising the retirement age, reducing the contribution rate, and building the second and third pillars of a multi-pillar pension system. If the PRC can do this, there is every chance that it can become an inclusive society that protects the elderly from economic deprivation and social marginalization. 


\section{REFERENCES}

Beijing News. 2017. Early Retirement Accounts for 30\%: Its Growth Needs to Be Curbed. May 7. In Chinese. http://www.bjnews.com.cn/opinion/2017/05/07/442443.html.

Chen, Qiulin, Karen Eggleston, and Ling Li. 2012. Demographic Change, Intergenerational Transfers, and the Challenges for Social Protection Systems in the People's Republic of China. In Donghyun Park, Sang-Hyop Lee, and Andrew Mason, eds. Aging, Economic Growth, and Old-Age Security in Asia. Cheltenham, United Kingdom: Edward Elgar.

Chen, Xi. 2017. Reducing Contribution Rate, Pension Fund Revenue and Pension Fund Balancing in Long Term. In Chinese. Chinese Journal of Population Science. (3). pp. 55-69, 127.

Dorfman, Mark, Robert Holzmann, Philip O’Keefe, Dewen Wang, Yvonne Sin, and Richard Hinz. 2013. China's Pension System: A Vision, Washington, DC: World Bank.

Dong, Keyong, and Gengyu Wang. 2016. China's Pension System: Achievements, Challenges and Future Developments. Economic and Political Studies. 4 (4). pp. 414-33.

Dong, Keyong, and Wenkai Shi. 2019. The Urban Employees' Basic Pension Insurance Unit Contribution Base: Evaluation, Problems and Countermeasures. In Chinese. Macroeconomics. (6). pp. 146-63.

Dong, Keyong. 2019. Establish and Develop the Third Pillar Personal Pension System with Chinese Characteristics. In Chinese. China Social Security. (3). pp. 34-36.

Government of the People's Republic of China, Ministry of Human Resources and Social Security. 2016. Annual Report on China's Social Insurance Development in 2016. Beijing: China Human Resources \& Social Security Press.

_ 2017. Data Summary of National Enterprise Annuity Funds Business in 2017. http://www. mohrss.gov.cn/SYrlzyhshbzb/shehuibaozhang/gzdt/201804/t20180404_291589.html.

Leckie, Stuart. 2011. Why Does Asia Need Well-Functioning Pension Systems. In Donghyun Park (ed.). Pension Systems and Old-Age Income Support in East and Southeast Asia: Overview and Reform Directions. New York: Routledge.

_ 2012. The People's Republic of China. In Pension Systems in East and Southeast Asia: Promoting Fairness and Sustainability. Manila: Asian Development Bank.

Lee, Sang-Hyop, Andrew Mason, and Donghyun Park. 2012. Why Does Population Aging Matter So Much for Asia? Population Aging, Economic Growth, And Economic Security in Asia. In Donghyun Park, Sang-Hyop Lee, and Andrew Mason, eds. Aging, Economic Growth, and Old-Age Security in Asia. Cheltenham, United Kingdom: Edward Elgar.

National Bureau of Statistics of China. 2018. China Statistical Yearbook 2018. Beijing: China Statistics Press. 
Park, Donghyun. 2009. Ageing Asia's Looming Pension Crisis. Asian Development Bank Economics Working Paper Series. No.165. Manila: Asian Development Bank.

Park, Donghyun, and Gemma Estrada. 2011. Why Does Asia Need Well-Functioning Pension Systems." In Donghyun Park, ed. Pension Systems and Old-Age Income Support in East and Southeast Asia: Overview and Reform Directions. New York: Routledge.

_. 2012. Introduction. In Pension Systems in East and Southeast Asia: Promoting Fairness and Sustainability, Manila: Asian Development Bank.

_ 2014. Emerging Asia's Public Pension Systems: Challenges and Reform Efforts. In Benedict Clements, Frank Eich, and Sanjeev Gupta, eds. Equitable and Sustainable Pensions: Challenges and Experience. Washington, DC: International Monetary Fund.

World Bank. 1994. Averting the Old Age Crisis: Policies to Protect the Old and Promote Growth. New York: Oxford University Press.

Sun, Yongyong. 2019. The Main Problems and Future of the Basic Pension Insurance Fund. SSL Working Paper Series. No. 068-20190604. Beijing: Chinese Academy of Social Sciences.

Yang, Yixin, and Wenjiong He. 2016. Can Increasing the Contributory Period Effectively Improve the Financial Sustainability of Pension Fund? Based on the Actuarial Evaluation of Pay-as-You-Go and Funded System. In Chinese. Population Research. 40 (3). pp. 18-29.

Zhao, Qing, and Haijie Mi. 2019. Evaluation on the Sustainability of Urban Public Pension System in China. In Chinese. Sustainability. 11 (5). pp. 1-20.

Zheng, Bingwen. 2017. Expansion of the Participation Rate: Options of Enterprise Annuities Reform. In Chinese. Chinese Journal of Population Science. (1). pp. 2-20,126.

Zheng, Gongcheng. 2015. From Regional Segmentation to National Pooling: The Only Way for Deepening Reforms in Urban Employees' Basic Pension Insurance System of China. In Chinese. Journal of Renmin University of China. (3). pp. 2-11. 


\section{Reforming Pension Insurance in the People's Republic of China}

A sound national pension insurance system is needed to sustain economic growth and provide income support to a nation's growing elderly population. This paper reviews the progress achieved by the People's Republic of China in strengthening its national pension insurance system during the 13th Five-Year Plan period, identifies the challenges and priorities for pension reform, and offers valuable recommendations.

\section{About the Asian Development Bank}

ADB is committed to achieving a prosperous, inclusive, resilient, and sustainable Asia and the Pacific, while sustaining its efforts to eradicate extreme poverty. Established in 1966, it is owned by 68 members49 from the region. Its main instruments for helping its developing member countries are policy dialogue, loans, equity investments, guarantees, grants, and technical assistance. 